\title{
Mountain parks in Norway - research and European collaboration
}

\author{
Morten Clemetsen \& Knut Biørn Stokke
}

Keywords: mountain parks, Norway, regional development

\section{Abstract}

A substantial proportion of large protected areas in Norway fall within mountain parks. Traditionally, the management of these areas has been rigid and wilderness oriented. In recent years, we have experienced a shift towards more integrated perspectives on the protection of nature and regional development. Parallel to this, several rural, bottomup regional park initiatives have emerged since 2005. The Norwegian regional parks and their strong international networks have proved to be important for new ideas of organization, collaboration and integrated management strategies for conservation and sustainable rural community development in Norway. As described in this paper, park management and research collaboration throughout Europe have influenced the Norwegian discourse of nature management and the country's research agenda.

$17 \%$ of the Norwegian mainland is protected under the Nature Diversity Act of 2009. The majority of all large protected areas (PAs) are located in mountain areas, along the Caledonian orogenic belt, which runs through the whole country. Traditionally, the management of these areas has been rather rigid and wilderness oriented, focusing on protecting nature from human activities (Skjeggedal \& Clemetsen 2017). Opportunities for opening up the areas for wider public access, beyond the simplest possible marking of trails, are limited.

The relationship between land-use planning for non-protected areas and environmental protection represents two contrasting paradigms (Stokke \& Haukeland 2017). On one hand, administrative rationale involves bureaucratic control based on scientific knowledge in environmental protection. Management regulations have merely tolerated people's right to roam, based on the public right of access to uncultivated land. Interpretation measures and paying for the services of professional mountain guides have generally not been accepted. On the other hand, the planning paradigm aims to change land use and the environment by striking a balance between different interests within a political rationale. However, due to changes in national conservation policies since 2003, a more diversified attitude to the economic potential of PAs for local communities in a regional context has emerged. In addition, since 2009, the responsibility for managing large PAs has been devolved from the state (the county governor) to inter-municipal boards, represented by the municipal and county councils concerned.

These changes are also prominent factors in regional parks initiated by bottom-up movements, which emerged in Norwegian mountain regions in the early 2000s (Skjeggedal \& Clemetsen 2017). In Europe, such parks generally fall within the IUCN Category V Protected landscapes, but the Norwegian regional parks were established outside national nature conservation regimes. Consequently, the relevance of strictly defined park boundaries is of lesser importance. On the other hand, their potential as tools for integrating nature protection, tourism and local development is greater.

Regarding both conservation policies and the emerging regional parks in Norway, inspiration from and collaboration with European research networks and park managers, have played a significant role. The theoretical and conceptual platform for advocating new regional park concepts in Norway was provided by Protected Areas and Regional Development in Europe, edited by Ingo Mose (2007). This publication generated the Norwegian nature conservation discourse and influenced several research projects. The ongoing BIOTOUR ${ }^{1}$ project on nature-based tourism is one such project, in which European research colleagues are also directly involved.

Inspired by the European Landscape Convention (Gambino \& Peano 2015), experts and proactive local community groups with active European networks introduced the idea of regional nature parks in Norway in the early 2000s. A series of study tours and visits to France, England and Switzerland from 2003 and onwards helped to conceptualize the first, pioneering, Norwegian regional park projects in the Nærøyfjorden and Valdres regions. In May 2009, the first national conference on regional parks in Norway took place at Stalheim, overlooking the spectacular scenery of the UNESCO World Heritage area of the West Norwegian fjord and mountain landscape. The NeReGro ${ }^{2}$ group from Central Europe was invited. Professor Ingo Mose (Oldenburg, Germany) and Professor Dominik Siegrist (Rapperswil, Switzerland) addressed issues of integrated community development, nature conservation and economic viability in regional parks. One spin-off from the conference was the book Landscape

\footnotetext{
Acronym for the research project From place-based resources to valueadded experiences. Tourism in the new bio-economy, Project no. 249463, financed by The Norwegian Research Council 2016-2020. The Norwegian University of Life Sciences (NMBU) manages the project in co-operation with four Norwegian and five international partner organisations.

Network Regionalentwicklung und Großschutzgebiete
} 
economy (Haukeland 2010), with contributions from the collaborating group of researchers from Switzerland, Austria, Germany and Norway. The book became a reader on the Master's course Strategic landscape planning at NMBU. At a later stage, in 2011, researchers and landscape managers from Norway met in the Chartreuse Parc Naturel Régional, France, to discuss PAs as tools for regional development. The collaboration with NeReGro was followed up in Norway in 2012 and again in 2015. The 2015 agenda focused on integrated visitor management and community development. The continuity between these meetings and the ongoing nature of the collaborations have had a significant impact on academic work on sustainable park models (Hammer et al. 2016).

Since the 2009 conference, and drawing particular inspiration from Switzerland, the Norwegian network of regional parks (Norske Parker) ${ }^{3}$ has grown from two to nine member parks. A number of candidacies for regional park status are also on-going, which means that approximately 70 Norwegian municipalities $(20 \%$ of the total number) are currently engaged in the regional park concept. With the formation of the European network for Regional Nature Parks, announced in Brussels in June 2017 and supported by the EUROPARC federation ${ }^{4}$ and the German association for nature parks, another great opportunity for international collaboration on research and best practice of integrated models is set to continue into the future.

One of the case areas in the BIOTOUR project is the Varanger peninsula in the sub-arctic region of Norway. The Varanger Peninsula National Park is among the largest on the Norwegian mainland, covering $2090 \mathrm{~km}^{2}$. It is quite remote and generally difficult to access for visitors. However, it is still an increasingly important asset for the surrounding communities. For its potential to be realized, one needs to take a broader perspective. The municipalities attached to the Varanger Peninsula National Park have recently launched a regional park, Varanger Arctic Norway. In our research, we investigate the awareness and capacity of the municipalities, local institutions and tourism actors to apply an integrated, regional perspective on nature conservation, nature-based tourism and community development in the regional context (Stokke \& Clemetsen 2017). As part of this, we have experimented with various ways of identifying and expressing the actors' practices and the values that they attach to the area through storytelling workshops. In turn, this awareness can be used to identify common landscape resources for integrated management and the creation of sustainable value. We plan to develop this further, in collaboration with European parks and research colleagues.

We can conclude this brief overview by stating that (a) the prevailing trend in Norwegian nature conser-

\footnotetext{
3 http://www.norskeparker.no

4 http://www.europarc.org/news/2017/05/first-europeansummit-regional-nature-parks/
}

vation is towards increased integration, in accordance with European practice; (b) the regional parks in Norway bring a bottom-up perspective on the landscape, which opens the way for wider regional cooperation across administrative borders. These are promising factors for realizing the sustainable value-added potential attached to protected areas in Norway.

\section{References}

Gambino, R. \& A. Peano. 2015. Nature Policies and Landscape Policies. Towards an Alliance.

Hammer, T., I. Mose, D. Siegrist \& N. Weixlbaumer (eds.) 2016. Parks of the future. Protected Areas in Europe Challenging Regional and Global Change. München.

Haukeland, P.I. (ed.) 2010. Landscape Economy. Contribution to sustainable value creation, landscape based entrepreneurship and place making. Examples from regional parks in Norway and Europe. Telemarksforsk report 263/2010 [n Norwegian] Available at: http://www.tmforsk.no/ publikasjoner/filer/1782.pdf

Mose, I. (ed.) 2007. Protected Areas and Regional Development in Europe. Towards a New Model for the $21^{15 t}$ Century. Aldershot.

Skjeggedal, T. \& M. Clemetsen 2017. Integrated and decentralized protection and development of mountain landscapes in Norway. Landscape Research 43(1): 64-76 Available at: http://dx.doi.org/10.1080 /01426397.2017.1291923

Stokke, K.B. \& M. Clemetsen 2017. Integrated planning of national parks and adjacent areas - potentials and limits in cooperation for nature-based tourism and place making. The $6^{\text {th }}$ International Symposium for Research in Protected Areas, Salzburg, Austria.

Stokke, K.B. \& J.V. Haukeland 2017. Balancing tourism development and nature protection across national park borders - a case study of a coastal protected area in Norway. Journal of Environmental Planning and Management. https://doi.org/10.1080/09640568.2 017.1388772

\section{Authors}

\section{Morten Clemetsen}

is a Landscape Architect and holds a PhD in integrated rural landscape planning and management. He is a Professor at the Norwegian University of Life Sciences, Faculty of landscape and society. E-mail: morten.clemetsen@nmbu.no

\section{Knut Bjørn Stokke}

is a human geographer with a particular interest in spatial planning. He is an Associate Professor at the Norwegian University of Life Sciences, Faculty of landscape and society. E-mail: knut.bjorn.stokke@ nmbu.no 